\title{
Effects of Fiscal Policy on the Exportation of Agricultural Products in Nigeria: A Vector Error Correction Model Approach
}

\author{
Emenyonu C. A*, Odii Marshall A. C. A, Onyemauwa C. S, Ulukwu O. C \\ Department of Agricultural Economics, Federal University of Technology, Owerri, Nigeria
}

Received April 3, 2020; Revised May 7, 2020; Accepted June 4, 2020

\section{Cite This Paper in the following Citation Styles}

(a): [1] Emenyonu C. A, Odii Marshall A. C. A, Onyemauwa C. S, Ulukwu O. C, "Effects of Fiscal Policy on the Exportation of Agricultural Products in Nigeria: A Vector Error Correction Model Approach," Universal Journal of Agricultural Research, Vol. 8, No. 5, pp. 146 - 157, 2020. DOI: 10.13189/ujar.2020.080502.

(b): Emenyonu C. A, Odii Marshall A. C. A, Onyemauwa C. S, Ulukwu O. C (2020). Effects of Fiscal Policy on the Exportation of Agricultural Products in Nigeria: A Vector Error Correction Model Approach. Universal Journal of Agricultural Research, 8(5), 146 - 157. DOI: 10.13189/ujar.2020.080502.

Copyright $\odot 2020$ by authors, all rights reserved. Authors agree that this article remains permanently open access under the terms of the Creative Commons Attribution License 4.0 International License

\begin{abstract}
The study examined the effects of fiscal policy on the agricultural products exports in Nigeria using Vector Error Correction Model (VECM) approach. Secondary data on agricultural export (AEX), total government expenditure (TGE), government expenditure on agricultural (GEA), tax on agriculture export (TAE), net food export (NFE), exchange rate (EXCH) and foreign direct investment (FDI) sourced from Central Bank of Nigeria Statistical Bulletin 2014 Edition. Trend analysis, Co-integration and VECM were used to achieve the objectives of the study. The results show that GEA was far below the 25\% FAO recommendation and AEX experienced occasional recessions. The result of the unit roots showed that only TAE, NFE and EXCH were stationary at level as indicated by their significant ADF-cal at $5 \%$. The coefficient of error correction terms was $-0.20791(\mathrm{p}<0.000)$ indicating a long run relationship between agricultural export and fiscal policy variables included in the model. GEA has no instantaneous positive effect on the agricultural export; TAE had crowding effect on the current export profile and increasing FDI did not significantly turn around the export profile of the sector but EXCH did. The Government should among others strive to attain the $25 \%$ budgetary allocation to agricultural sector to encourage agricultural exportation.
\end{abstract}

Keywords Agricultural Export, Fiscal Policy, Vector Error Correction Model (VECM)

\section{Introduction}

Agricultural export commodities contributed well over $75 \%$ of total annual merchandise exports in the 1960s. Nigeria was the largest exporter of palm-oil and palm-kernel; ranked second in cocoa and occupied a third position in groundnut (Abolagba et. al., 2010; Ekpo and Egwakllide, 1994). The accrued earnings from agricultural export in Nigeria have brought numerous benefits to Nigeria and the continent at large. The government revenue depended heavily on agricultural export taxes and both the current account and fiscal balances depended to some extent on agriculture before the discovery of oil (Folawewo and Olakojo, 2010).

Since the oil-boom era of the 1970s, the contributions of agriculture to foreign earnings have remained abysmally low, representing less than $1 \%$ between 2000 and 2004 (CBN, 2005), agricultural sector's export was negligible and represent about 0.2 per cent of the total exports in the country. The major cause of the decline in agricultural exports had been linked to increased investment in the oil sector (CBN, 2005). The reduction in agricultural activities has caused a high level reduction in local food production, making Nigeria one of the leading nations in importation of food to supplement local production, which leads to 
growing importation and falling export earnings (Diao et. al., 2007).

This scenario was blamed by many on the inadequate funding of the agricultural sector which they said had been an obstacle to increased agricultural output, dwindling trend of agricultural exportation and unpleasant large import bill (CBN, 2007; Bernard, 2009). However, from a nominal point of view, it is evident that in Nigeria, government spending on agriculture continued to increase over the years while empirical evidence has revealed that the performance of the agricultural sector has been inadequate (CBN, 2000; Ekerete, 2000). Government intervention programmes over the years such as River Basins and Rural Development Authorities, the Agricultural Development programmes, ADP, Operation Feed the Nation (OFN), Green revolution, Cassava Promotion Initiative and Back to Farm programme, and most recently, the government's Agricultural Transformation Agenda launched in 2011 with greater emphasis on Farmers' Growth Enhancement Scheme and improved Value Chain of Agricultural production had not yielded desired objectives. All these interventions are anchored on fiscal policy of the government and economic stabilization policy with utmost intention to improve agricultural productivity, boost domestic production, reduce food import bills and improve foreign exchange through agricultural exportation (Agricultural Transformation Agenda Blue print, 2013)

Despite all these, agriculture has failed to keep pace with Nigeria's rapid population growth. Nigeria, once a major exporter of food, now relies on imports to sustain its growing population. Smallholder and traditional farmers who constitute a dominant proportion of Nigerian farmers still operate under rudimentary production techniques, with resultant low yields, and abysmally low agricultural export profile. They are constrained with poor access to modern inputs and credit, poor infrastructure, inadequate access to markets, land and environmental degradation, and inadequate research and extension services. Nigeria's agricultural sector now faced with several emerging problems which constrained the full realization of its full potentials. These problems include; inadequate supply and delivery of farm inputs, shortage of working capital, low level of technology, diseases and pest infestation, lack of credit facilities among others and low repayment of credit disbursed among rural farmers (Njoku and Odii, 1991).

Over the years, government has almost been the sole provider of financial and other capital resources to support agriculture. Government has attempted to increase her expenditure on agriculture through budgetary allocation and through the provision of cheap and readily available credit facilities (Nwosu 2004; Iganiga and Unemhilin, 2011). Itodo et. al, (2012) revealed that the Nigerian Agricultural and Corporative Bank (NACB) was also established in 1973 as part of government's effort to channel oil fund into agriculture through the provision of credit facility to sustain agriculture and agro-based ventures (Olagunju, 2000). However, FAO (2008) reported that in terms of capital allocation to agriculture in Nigeria, it was an average of 4.74 percent from 1970-1980. But, from $1980-2000$, it rose to 7.00 percent and 10 percent from 2001-2007, though revealing an increase, but still falls short of Food and Agricultural organization (FAO, 2004) recommendation that 25 percent of government capital budget be assigned to the agricultural development capital budget. Iganiga and Unemhilin, (2011) in their study stressed that government allocation to agriculture is relatively low and that actual expenditure falls short of budgetary expenditure and the rate of under-spending is usually higher for agriculture than for other economic sectors. The 1986 devaluation of the naira increased the demand for agricultural products and raised prices of agricultural commodities over the years (Adubi and Okunmadewa, 1999). The fluctuations, frequency and instability of the exchange rate movements since the beginning of the floating exchange rate have raised a concern about the impact of such movements on agricultural trade flow in Nigeria and empirical studies of the impact of FDI on growth are concerned with either the overall effect on growth (or net welfare) or with specific aspects of the FDI impact on employment, technology, trade, entrepreneurship and other areas of the economy, such as, infrastructures, education and health. Thus, the impact of FDI on economic growth remains unclear and regrettably, Nigeria agricultural output has been on a decline when compared with other sectors of the economy. The decline has also resulted in a seemingly decrease in the agricultural revenue base of the country especially as it relates to tax generated by the trade in the export of agricultural products (Nwibo, et. al., 2012; Nwibo, 2012; Adubi and Okunmadewa, 1999)

Several literatures had pointed out that the major goal of successive Governments is to diversify the Nigerian economy and transform it from monolithic economy to a more vibrant multi-sectoral economy with special interest in agricultural sector through increased government expenditure and other stabilization policy efforts towards the sector (Abolagba et. al., 2010; Chigbu 2000; Emeka 2007; Ekerete 2001; Iganiga and Unemhilin 2011). However, as Government expenditure on agricultural production and other developmental programmes increase, there tend to be an opposite scenario in agricultural production and exportation as evidenced by its sharp decline, leading to food insecurity and high food import bill as expressed by Ajakaiye and Fakiyesi (2001). Hence there is need to evaluate the justification of Government spending on agricultural production and provide policy recommendations to help the policy makers, fiscal/monetary authorities such as the Ministries of Finance, Economic Planning, Central Bank of Nigeria and policy implementing executives to ensure a vibrant Nigerian agricultural sector through the fiscal policy. The specific objectives are to describe the performance of Nigerian agricultural export, empirically investigate the 
effect of some fiscal policy variables on agricultural export in Nigeria over the last three decades and describe the effect of fiscal policy and hence degree of responsiveness of agricultural export to slight change in some fiscal policy variables.

\section{Methodology}

The study area is Nigeria, which is officially referred to as the Federal Republic of Nigeria. It is a country in West Africa which shares land borders with the Republic of Benin in the West, Chad and Cameroon in the East, Niger in the North, and borders the Gulf of Guinea in the South. It is on the latitude $10^{\circ} \mathrm{N}$, longitude $8^{\circ} \mathrm{E}$, its climate varies from equatorial in the South, tropical in the center and arid in the North. According to NPC (2006), Nigeria has a total population of $140,003,542$ people. It has a total area of $923,768 \mathrm{~km}^{2}$ out of which 5,000 sq miles is water, $33.0 \%$ of the land mass is arable and $13.0 \%$ on permanent cropping, Her major agricultural products include groundnuts, palm oil, cocoa, rubber, coconut, citrus fruits, maize, millet, cotton, cassava, yam and coffee among others. It also had a booming leather and textile industry, with industries located in Kano, Abeokuta, Onitsha and Lagos. Tax revenue has been its second largest source of revenue after oil export.

The study employed only secondary data of time series spanning from 1980 to 2014. Data collected were on agricultural export (AEX), total government expenditure (TGE), government expenditure on agriculture (GEA), tax on agriculture export (TAE), net food export (NFE), exchange rate (EXCH) and foreign direct investment (FDI). These data were sourced from Central Bank of Nigeria (CBN) Statistical Bulletin, 2014 covering a period of 30 years $(1983-2013)$.

The study employed both Descriptive statistics (time trend analysis), Co-integration and Vector Error Correction Model (VECM) to achieve the objectives of the study. The structure and trend of the agricultural export expressed as value of Agricultural export and fiscal policy tools such as Government expenditure, government expenditure on agric, Agricultural tax, net food export, exchange rate and foreign direct investment were described with the use of charts. The technique of co-integration to empirically investigate the effect of some fiscal policy variables on agricultural export, it is essential to first check the presence of unit root (non-stationary). The Augmented Dickey Fuller (ADF) test was used to test for unit roots as in the (eq1)

$$
\Delta Y_{t}=C_{i}+\omega Y_{t-1}+C_{2 t}+\sum_{t-1}^{p} \delta_{i} \Delta Y_{t-1}+\varepsilon_{t} \quad(\text { eq1 })
$$

Where: $\mathrm{Y}_{\mathrm{t}}=$ relevant time series, $\Delta=$ an operator for first difference, $\mathrm{t}=\mathrm{a}$ linear trend and $\varepsilon_{\mathrm{t}}=$ error term. The null hypothesis of the existence of a unit root is Ho: $\omega=0$. Failure to reject the null hypothesis leads to conducting the test on further differences of the series.

The choice of a co-integration technique over the ordinary least square techniques was that most time series data are not stationary, so the use of the OLS method of estimation could only yield a spurious result. The Johansen procedure was used to test for the number of co-integration vectors in the model. Johansen technique was used not only because it is vector auto-regressive based but because it performs better in multivariate models and as variables used in the model are co-integrated, their short-run and long- run dynamics was captured by Vector Error Correction Model (VECM). (Maddala, 2001) and the Vector Error Correction Model (VECM) was used in the study to ascertain both Short-run and long-run effects. VECM captured the degree of responsiveness of value of Agric. export to the unit change of each of the fiscal policy tools as in (eq2):

$$
\begin{gathered}
A E X_{t}=\beta_{0}+\beta_{1} E C M_{t-1}+\beta_{2} T G E_{t}+\beta_{3} G E A_{t}+ \\
\beta_{4} T A E_{t}+\beta_{5} N F E_{t}+\beta_{6} E X C H_{t}+\beta_{7} F D I_{t}+\varepsilon_{t} \text { (eq2) }
\end{gathered}
$$

where: $\mathrm{AEX}=$ Value of Agric Export in (\$'billion); $\mathrm{ECM}_{\mathrm{t}-1}=$ Error Correction Coefficient; TGE $=$ Total Govt Expenditure in (\#'billion); GEA = Govt. Expenditure on Agric in (\$'billion); TAE = Tax charged on Agric Export in (N'million); NFE = Net Food Export which is the difference between Export and Import of Food Commodities in ( $\mathbb{N}^{\prime}$ billion), $\mathrm{EXCH}=$ Exchange rate $(\mathrm{N} / \mathbf{\$})$ in ( $\mathrm{N})$; FDI = Foreign direct Investment in (\$'billion) and $\varepsilon_{\mathrm{t}}=$ Stochastic Error term measuring excluded variables

\section{Results and Discussion}

\section{Structure and Trends in Fiscal Policy Instruments}

Result of findings presented in figure 1 shows that Government expenditure on Agriculture sector was N0.01billion in 1983 and rose to $\$ 1.80$ billion in 1993 and \#9.99 billion in 2002, but declined to \$7.54 billion in 2003 and thereafter witnessed a steady rise in the next five years to $\mathbf{N 6 5 . 4}$ billion in 2008. It was however short-lived as it declined significantly to $\$ 22.4$ billion in 2009 and experienced undulating patterns from then till it was 39.4 billion in 2013. This indicated inconsistent fund availability to agricultural sector of the economy. 


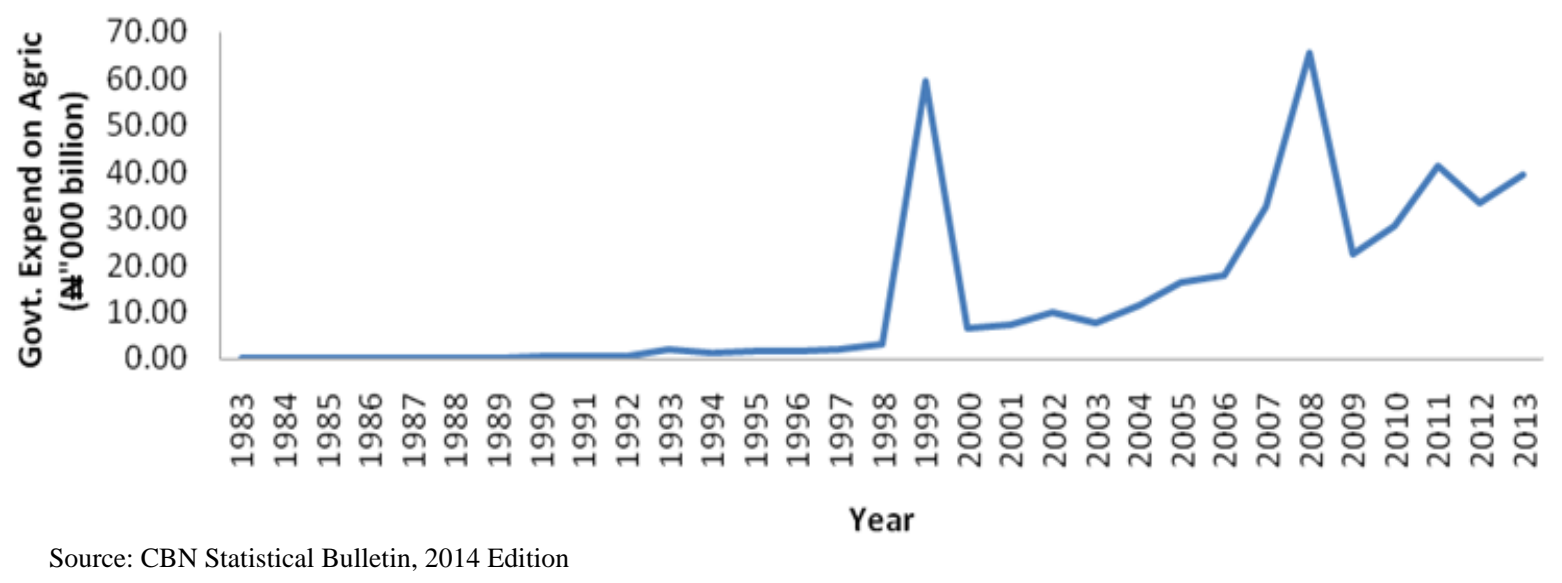

Figure 1. Government expenditure on Agriculture in \#’000 billion
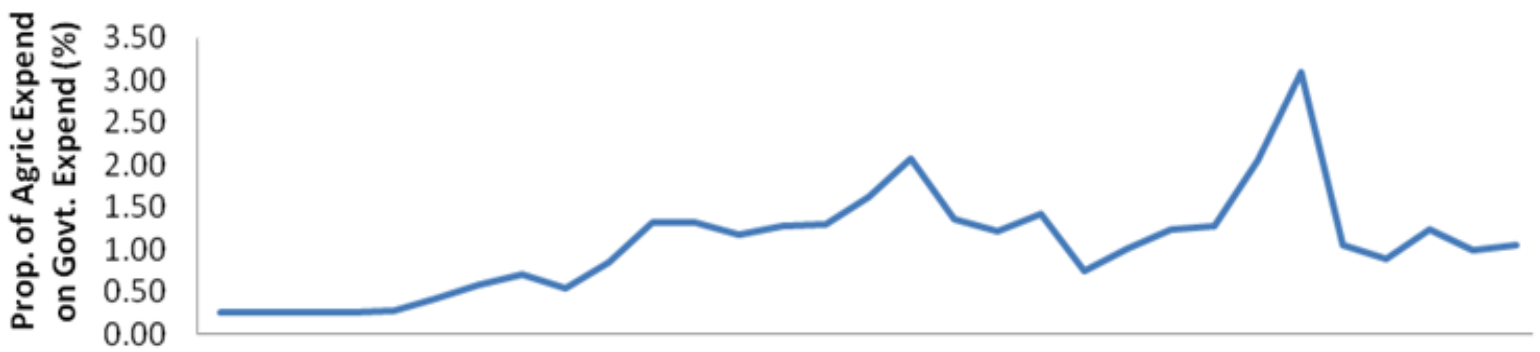

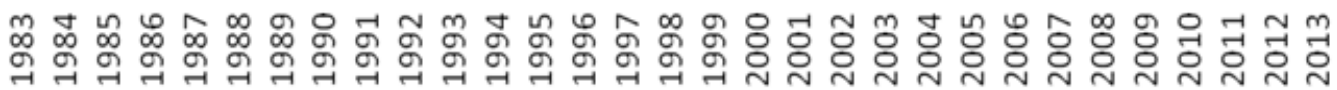

Year

Source: CBN Statistical Bulletin, 2014 Edition

Figure 2. Proportion of Government Expenditure on Agriculture (GEA) in Total Government Expenditure (TGE).

The implication of this inconsistent and low government funding resulted in inadequate agricultural finance to the small holder farmers which had culminated into low productivity, low income and low capital investment by the small holder farmers in agricultural sector. This result is consistent with the findings of Iganiga and Unemhilin (2011) and that of Nwosu (2004) who reported that government has almost been the sole provider of financial and other capital resources to support agriculture over the years.

Proportion of Government expenditure to agriculture expressed as percentage of Government Expenditure to Agriculture was below 3.50\% over three decades under review as shown in figure 2. It was $0.27 \%$ in 1983 and remained unchanged till 1986 . It rose to $0.71 \%$ in 1990 but declined to $0.55 \%$ in 1991 . The value was $1.32 \%$ in 1993 and experienced steady increase till it became $2.7 \%$ in 1999 , only to drop sharply to $1.37 \%$ in 2000 . The highest percentage was $3.09 \%$ in 2008 but declined sharply to $1.05 \%$ in 2009 and was unsteady ever since till it was
$1.07 \%$ in 2013.

This available fund always fell short of FAO recommendation of $25 \%$ of government capital budget to the agricultural development capital budget, more so a large proportion of the funds allocated to agriculture does not go directly to farmers who are mostly small holder farmers, scattered across the country. This implied that government expenditure in agriculture was unimpressive over the years and the shortage of government expenditure was obvious in the low investment in agriculture, poor agricultural productivity and low exportation of agricultural commodities witnessed over the years. As shown in figure 3 , the value of tax on agriculture was \$5.07 million in 1983 and rose to $\$ 14.28$ million in 1989, it increased steadily to \$106 million in 1997 and ever since then had been on increasing trend till 2004 when it stood at \$268.12 million, it thereafter dropped significantly to $\$ 169.68$ million in 2005 and returned to growing pattern after years till it became N806.92 million in 2013. 


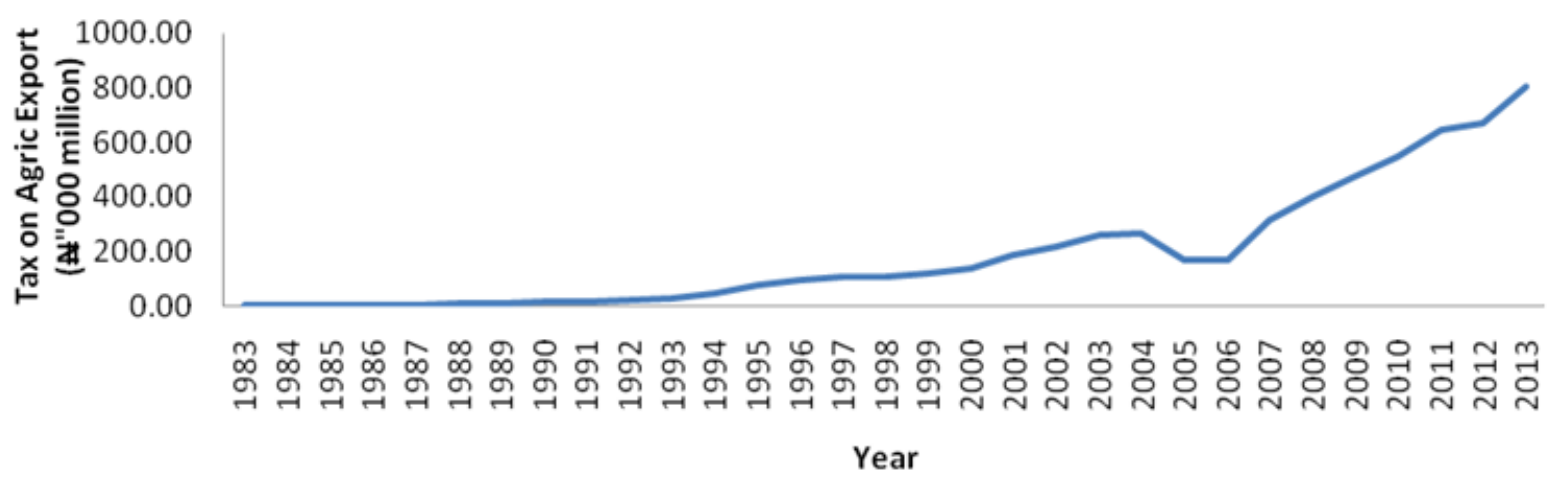

Source: CBN Statistical Bulletin, 2014 Edition

Figure 3. Tax on Agricultural Export (TAE) in ॠ’000 million

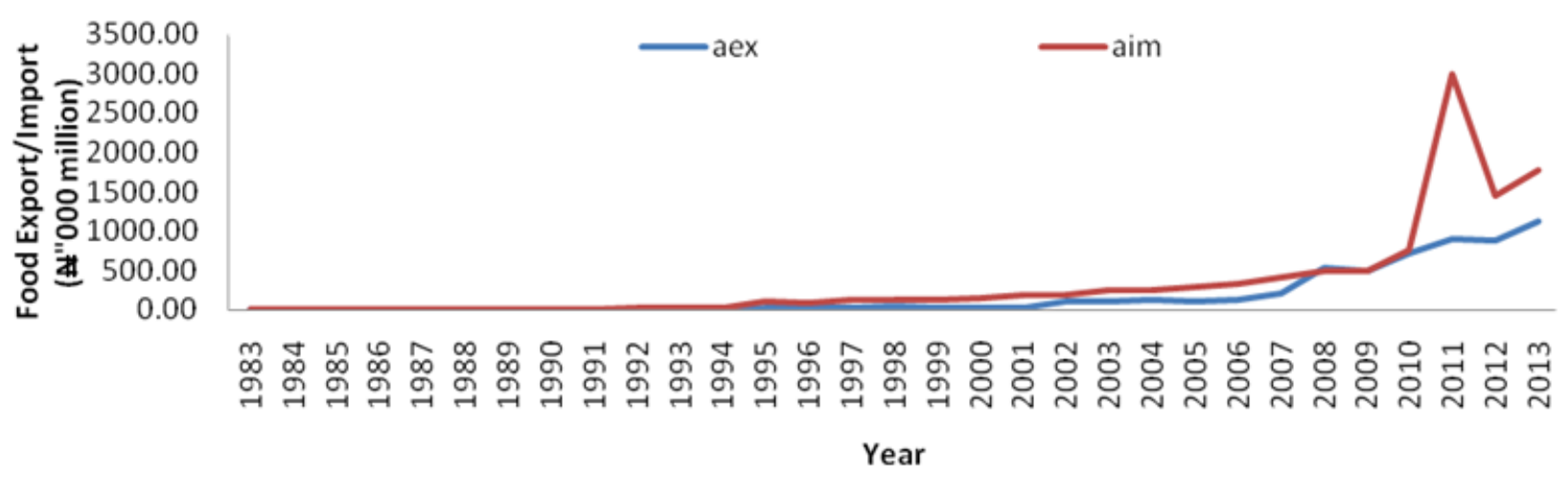

Source: CBN Statistical Bulletin, 2014 Edition

Figure 4. Net Food Export (NFE) in ( ${ }^{\prime} 000$ million)

This unstable trend could be associated with inconsistent trend of agricultural growth and export activities in the year under review. This finding is consistent with the observations of Nwibo (2012), Folawewo and Olakojo (2010) and Nwachukwu et. al. (2008) that reported that the accrued earnings from agricultural export in Nigeria have brought numerous benefits to Nigeria and the government revenue depended heavily on agricultural export taxes before the oil boom which had drastically reduced afterwards resulting from falling export earnings. This implied that increased tax charged on agricultural export could reduce the earnings of the exporting farmers, firms and industries which might act as a disincentive to export agricultural commodities and ultimately reduce government earnings. The result of net food export presented in figure 4 shows that food export and import were below $\$ 500$ million respectively till 1985; there was net food export surplus all through 1987 till 1991 as the food export and import rose to $\$ 2.15$ billion and $\$ 1.97$ billion in 1987, \$2.95 billion and \$2.32 billion in 1989 respectively and $\$ 4.68$ billion and $\$ 3.57$ billion in 1991 respectively. This net food export surplus was however short-lived as food import rose to 15.03 billion while food export dropped to $\$ 4.23$ billion in 1992, both food export and import rose to $\$ 4.9$ billion and $\$ 15.78$ billion respectively in 1994 resulting in net food export deficit. However, food export grew to $\$ 525.86$ billion in 2008 and $\$ 500.86$ billion in 2009 while food import was $\$ 493.03$ billion in 2008 and $\$ 498.40$ billion in 2009 respectively. These net food export surplus were short-lived again as food import grew to $\$ 2.99$ trillion, $\$ 1.44$ trillion, $\$ 1.77$ trillion in 2011, 2012 and 2013 respectively while food export was only increased to $\$ 913.51$ billion, $\$ 879.34$ billion and $\$ 1.13$ trillion respectively in the same period. There was a long stay of net food export deficit as food export concurrently fell short of food import over the years and this net trade balance deficit value which implies that Nigeria remains a net importer with regards to agriculture resulting in rising food import bill, lowering foreign exchange earnings from agricultural export and government receipts from agricultural revenue and in extension resulted in general rise in food prices, food insecurity, high cost of living and eroded real income of the citizenry of the country.

This finding is consistent with those of Olarinde and Abdullahi (2012) and Abolagba et al (2010) who posited that increased food import bills coupled with the already depreciating exchange rate were the leading cause of food insecurity in the country.

As indicated in figure 5, it was shown that the exchange 
rate was 0.72 to 1 US\$ in 1983 , it rose to $\$ 2.02$ to 1US\$ in 1986, $\$ 17.30$ to 1US\$ in 1992 and assumed a stable value of $\$ 21.90$ to 1US\$ through 1993 to 1998, but thereafter rose rapidly to $\$ 92.69$ to 1US\$ in 1999, $\$ 133.66$ to 1US\$ in 2004, dropped to 128.65 to 1US\$ in 2006 then continue a significant rising trend ever since to $\$ 142.65$ to 1US\$ in 2009, $\$ 152.28$ to 1US\$ in 2011 and $\$ 161.81$ to 1US\$ in 2013. This indicated that Nigerian Naira's currency against United State of America (USA) Dollar's currency has been devalued over the years especially since 1986 when naira dipped down from $\$ 0.89 / 1$ US\$ in 1985 to \#2.02 to 1US\$ in 1986 and has significantly dipped further since then. It is reported that since 1986, Nigeria had been experiencing erratic changes in her exchange rates partly due to fluctuations in the major currencies of developed countries such as dollars, pound sterling and Swiss franc. The implication of the instability of Nigeria's currency could be the reason for the fluctuation in the demand for agricultural products in the international market over the years as .the fluctuation, frequency and instability of the exchange rate movements since the beginning of the floating exchange rate adopted in 1986 had impacted the movements of agricultural trade flow and export revenue in Nigeria. This findings in consistent with studies of Okunmadewa (1999), Kargbo (2006) and Ettah et. al. (2011).

As shown in figure 6, the foreign direct investment into Agricultural sector was $\$ 1.62$ billion in 1983 which increased to 6.23 billion in 1988 but dropped to $\$ 4.69$ billion in the following year, it experience high volatility over the years with occasional dip values of \$5.61 billion and $\$ 7.83$ billion. It however experienced increasing trend with lowest and highest values of $\$ 13.53$ billion and N41.73 billion in 2003 and 2006 respectively and about \#18.33 billion in 2013.

The unstable inflow of foreign investments in form of capital projects in agricultural development could be linked to political instability and non-sustenance of government foreign policy.

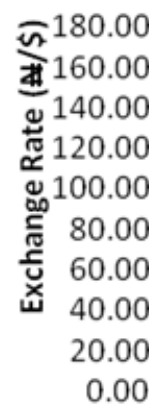

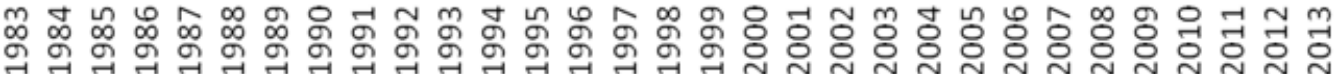

Year

Source: CBN Statistical Bulletin, 2014 Edition

Figure 5. Exchange Rate (EXCH) in ( $₫ / 1 U S \$)$

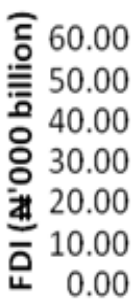

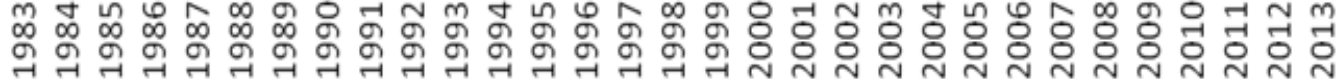

Year

Source: CBN Statistical Bulletin, 2014 Edition

Figure 6. Foreign Direct Investment (FDI) in N' 000 billion 


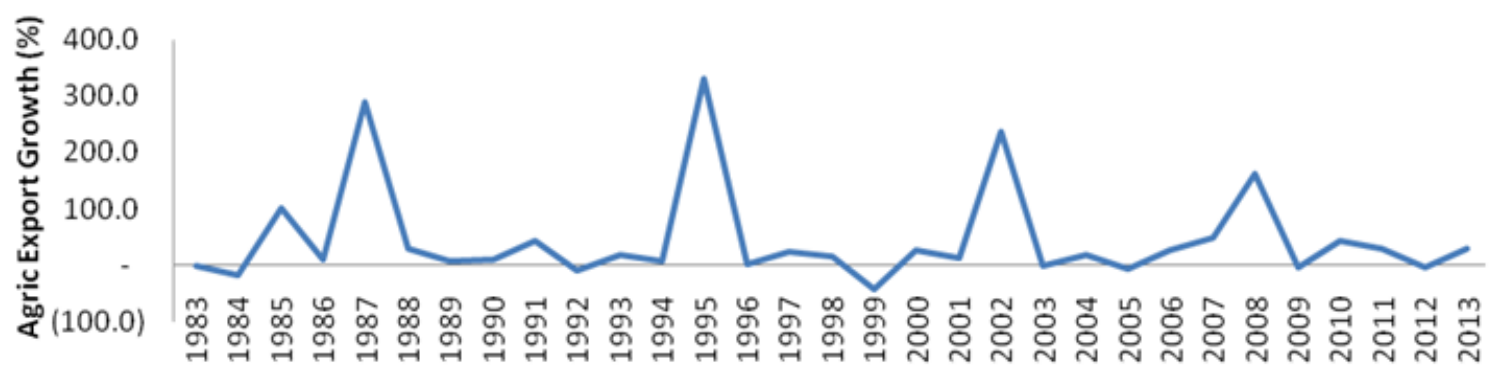

Year

Source: CBN Statistical Bulletin, 2014 Edition

Figure 7. Agric Export Growth (\%)

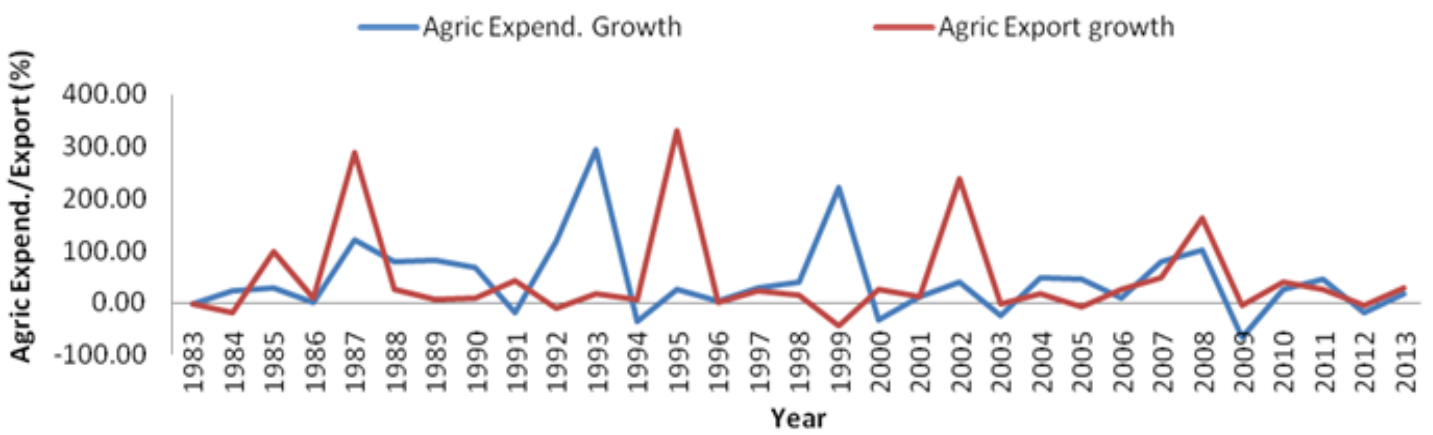

Source: CBN Statistical Bulletin, 2014 Edition

Figure 8. Effects of Growth in Agric Expenditure on Agric Export (\%)

\section{Performance of Nigerian Agricultural Export over the years}

As illustrated in figure 7, the performance of agricultural export decreased by $17.9 \%$ from $\$ 0.3 b i l l i o n$ in 1983 to $\$ 0.2$ billion in 1984. It increased to $\$ 0.5$ billion in 1985 (100.9\%), followed by recession of about $11.1 \%$ in 1987 and picked up by $289.8 \%$ in 1988 . The periods of booms of $28.1 \%$, 43.5\%, 331.8\%, 238.2\%, 163.9\% and 28.5\% in 1998, 1991, 1995, 2002, 2008 and 2013 respectively were occasionally interrupted with recessions of $-9.6 \%,-42.8 \%$, $-6.5 \%,-4.8 \%$ and $-3.7 \%$ in 1992, 1999, 2005, 2009 and 2012 respectively. This indicated unsteady movements of growth in agricultural exports over the last three decades. This collaborate the findings of Folawewo and Olakojo (2010) that observed a similar trend in agricultural export inconsistent rise and fall within the period.

\section{Effects of Growth in Agric Expenditure on Agric Export (\%)}

The effects of Agricultural expenditure on Agricultural export as illustrated in figure 8 showed that agricultural expenditure increased to $22.66 \%$ while food export dropped by $17.9 \%$ in 1984 . The influence of agricultural expenditure was significant on food export in 1995 when food export rose by $331.8 \%$ with only $27.64 \%$ rise in agricultural expenditure. This effect was also experienced in 2002 as $41.46 \%$ increase in agricultural expenditure led to $238.2 \%$ increase in food export. It is worthy of note that agricultural export was unaffected despite reduction in agricultural expenditure by 24.58\% in 2003 .

A significant rise of $101.33 \%$ in agricultural expenditure led to increase of $163.9 \%$ in food export in 2008 and significant fall of $65.69 \%$ and $19.12 \%$ in agricultural expenditure resulted to $4.8 \%$ and $3.7 \%$ fall in food export in 2009 and 2012 respectively. The rise of agricultural expenditure by $45.9 \%$ and $18.41 \%$ in 2011 and 2013 respectively led to $28.5 \%$ rise in food export in the same years. The unsteady movements of agricultural expenditure had resulted to food export fluctuations over the years. This implies that agricultural expenditure has significant negative effect on the agricultural production and export growth as the fluctuation in agricultural expenditure contributed immensely to the unstable agricultural growth of the country. This is consistent with the findings of Nwibo et. al. (2012)

\section{Effect of Fiscal Policy Variables on Agricultural Export in Nigeria}

\section{Stationarity Test}

For the testing of unit roots, the Augmented Dickey-Fuller test (ADF) was used and the result as presented in Table 1 shows that the TAE, NFE and EXCH were stationary at level as indicated by their ADF-cal which are higher than ADF-tab at 5\%, therefore they are regarded as series stationary at level i.e. I(0). However, AEX, GE, GEA and FDI were not stationary at level but only stationary at first difference i.e. I(1) since their ADF-cal at 5\% was less than ADF-tab values at 5\% at level 
but greater than ADF-tab values at $5 \%$ at first difference.

This observation of unit root in AEX, GE, GEA and FDI makes it undesirable to establish a statistical relationship with any other time series variables under study; thus an attempt to regress via ordinary least square gave a spurious estimate since it is not stationary at level. However, when the unit roots tests were conducted at first difference, they became stationary as indicated by their ADF-cal at first difference. According to Iganiga and Unemhilin (2011) and Akintude et. al. (2013), when time series were all integrated at $\mathrm{I}(1)$, it presumes long-run relationships existing among the agricultural export and fiscal policy variables in the model.

\section{Co-integration analysis}

Since a unit root has been confirmed for four data series as indicated in the unit root tests that the variables under examination are integrated of order 1 , there is possibility for the existence of a long-run equilibrium relationship which implies that their stochastic trends must be linked among a given set of variables and a test for co-integration was a useful pre-test to avoid spurious regression situations. Therefore, Johansen co-integration test was conducted since the Johansen-Juselius test gives better results and apply maximum likelihood rather than the least square estimation procedure. According to Table 2, the null hypothesis is that the number of co-integrating vectors is less than or equal to $r$, where $r$ is $0,1,2,3,4,5$. Accordingly, the null hypothesis was rejected if the calculated trace and/or maximum statistics is greater than their corresponding tabulated values, otherwise they are accepted. The calculated trace and maximum statistics at null hypothesis of $r \leq 4$ were $2.7080^{*}$ and $2.7080^{*}$ respectively with corresponding tabulated values of 3.76 respectively, the null hypothesis was accepted at this stance which implies that there are at least four co-integrating vectors at $0.01 \%$ critical level, denoting a long- run relationship of the fiscal policy variables with agricultural export.

This suggests the existence of four co-integrating vectors in the model, we can conclude that the agricultural export and fiscal policy variables are co-integrated and follow long-run equilibrium relationship. According to Akintunde et. al, (2013), the evidence of co-integration rules out spurious regression and hence suggests the Error Correction Model, which is an attempt to integrate economic theory useful in characterizing a long-term equilibrium with an observed disequilibrium by building a model that explicitly incorporates behaviour that would restore the equilibrium. Akintude et. al., (2013) assert further that the use of the VECM is facilitated when variables are first-differenced stationary and cointegrated. According to Gujarati, (1995), Error Correction models is a useful tool to evaluate the short term, long run (long run multiplier) effects of Independent variables on dependent variables and the speed of adjustment of dependent variable to the equilibrium after a deviation has occurred.

Table 1. Result of Unit root tests

\begin{tabular}{|c|c|c|c|c|}
\hline Variables & $\begin{array}{c}\text { ADFvalue@ } \\
\text { level }\end{array}$ & $\begin{array}{c}\text { ADFvalue@ } \\
\text { 1st diff. }\end{array}$ & $\begin{array}{c}\text { ADFvalue@ } \\
\text { 2nd diff. }\end{array}$ & Remarks \\
\hline AEX & -1.683 & $-2.699 * * *$ & $-2.650 * *$ & $\mathrm{I}(1)$ \\
\hline GEA & -1.893 & $-2.196 * *$ & $-2.156^{* *}$ & $\mathrm{I}(1)$ \\
\hline TAE & $-4.310 * * *$ & $-5.307 * * *$ & $-11.303^{* * *}$ & $\mathrm{I}(0)$ \\
\hline FDI & -1.608 & $-4.436 * * *$ & $-9.276 * * *$ & $\mathrm{I}(1)$ \\
\hline
\end{tabular}

$* * *, * *=$ significant at $1 \%, 5 \%$

Source: Results of the Data Analysis, 2016

ADF tab@5\%,1\%=-1.950, -2.654 respectively

Note: $\mathrm{I}(0)=$ stationary at level, $\mathrm{I}(1)=$ stationary at first difference.

Table 2. Co-integration rank of a VECM model

\begin{tabular}{cccccccc}
\hline $\begin{array}{c}\text { Null } \\
\text { Hypothesis }\end{array}$ & $\begin{array}{c}\text { Alternative } \\
\text { Hypothesis }\end{array}$ & $\begin{array}{c}\text { Log-likelihood } \\
\text { Value }\end{array}$ & Eigen-value & $\begin{array}{c}\text { Trace } \\
\text { statistics }\end{array}$ & $\begin{array}{c}\text { Max. } \\
\text { statistics }\end{array}$ & $\begin{array}{c}\text { 1\%crit. } \\
\text { value (trace) }\end{array}$ & $\begin{array}{c}\text { 1\% crit. } \\
\text { value (max.) }\end{array}$ \\
\hline $\mathrm{r}=0$ & $\mathrm{r}=1$ & -1285.136 &. & 365.425 & 191.098 & 68.52 & 33.46 \\
$\mathrm{r} \leq 1$ & $\mathrm{r}=2$ & -1189.587 & 0.99891 & 174.3270 & 83.0981 & 47.21 & 27.07 \\
$\mathrm{r} \leq 2$ & $\mathrm{r}=3$ & -1148.038 & 0.94858 & 91.2289 & 60.4250 & 29.68 & 15.41 \\
$\mathrm{r} \leq 3$ & $\mathrm{r}=4$ & -1117.825 & 0.88445 & 30.8039 & 28.0959 & 20.97 \\
$\mathrm{r} \leq 4$ & $\mathrm{r}=5$ & -1103.777 & 0.63338 & $2.7080 *$ & $2.7080 *$ & 3.76 & 3.76 \\
\hline
\end{tabular}

* indicated the co-integration rank selected were based on trace and maximum statistics.

Source: Results of the Data Analysis, 2016. 


\section{Effects of Fiscal Policy and Degree of Responsiveness of Agricultural Export}

The Vector Error Correction Model (VECM) was carried out and the result is presented in Table 3. The estimates of the VECM model showed the short and long run relationships of the contemporaneous and lagged series of the agricultural export, fiscal policy and other macro-economic variables used in the model. The Log-likelihood ratio of $513.407(\mathrm{p}<0.000)$ implies that the model fit well in explaining the effect of relationship existing amongst the AEX, GE, GEA, TAE, NFE, EXCH, FDI as specified in the model. It further shows that there exist long run relationship between agricultural export and fiscal policy variables and other macro-economic variables included in the model and it takes more years to attain equilibrium.

The parameter estimates of Error Correction (ECM(-1)) which measures the speed of adjustment of the agricultural export to the equilibrium when a disturbance has occurred in the model was $-0.2079(\mathrm{p}<0.00)$, this magnitude of -0.2079 indicates that about $20.79 \%$ of the previous year disequilibrium in agricultural export is adjusted for in the following year. This implies that stochastic error (residuals) processes generated and their movements with time in the models can be corrected and the speed of adjustments back to equilibrium in the long run were given as $20.79 \%$. It reflects a feedback of the previous year's disequilibrium from long run elasticity of the explanatory variables and the speed at which the level of agricultural export adjusts to changes in the explanatory variables in an effort to achieve long run static equilibrium.

The coefficients of AEX (-1) and AEX (-2) were -0.3863 and -0.7307 respectively and significant at $5 \%$ statistical level respectively which implies that the one-year and two-years lagged values of agricultural export have negative significance short run effects on current agricultural export. This is an indication of declining trend of agricultural exports over the years which reflect the downward patterns that agricultural export had been experiencing since in oil boom in the early 70s when the government attention had been diverted to downstream sector of the economy leaving the agricultural sector to suffer colossal loss over the years. This observation is in line with observations of Nwibo (2012) and CBN (2005) that agricultural exports have remained abysmally low, representing less than 1\% between 2000 and 2004 .

The coefficients of TGE(-1) and TGE(-3) were -0.2167 and 0.2806 respectively and significant at $5 \%$ statistical level. This indicates that one-year and three-year lagged values of government expenditures had significant short run effects relationship on agricultural export. This implies that government expenditure did not have instantaneous positive effect on the agricultural export rather a negative effect as indicated by the one-year lagged value. This could partly be due to the fact that when government funds injected in development programs did not have instantaneous positive effect on the agricultural productivity. This result is consistence with the views of Iganiga and Unemhilin (2011) that noted that this contemporaneous capital expenditure in agriculture did not have instantaneous effects on agricultural production.

The coefficients of GEA(-1) and GEA(-2) were 1.8256 and 1.4223 respectively and significant at $5 \%$. This indicates that the penultimate year and two- year lagged government expenditures on agriculture had positive significant short run effects on the agricultural export. The positive coefficient of the government expenditure on agriculture indicates that increases in government expenditure to agricultural sector could translate to desired increased agricultural productivity and exportation. However, the three-year government expenditure (GEA) was -0.234 , shows that it had negative effect on agricultural export, though not significant at 5\% but implies that the late disbursement of agricultural finance to intended users could have negative effect on agricultural export. This result shares a common view with Okuneye (2002) and Omanukwue (2007) that attributed the poor performances of the agricultural export in Nigeria to underfunding, late disbursement of agricultural finance to intended beneficiaries and high level of official corruption and bad governance which played out in diversion of funds to unintended beneficiaries.

The coefficients of TAE(-1), TAE(-2) and TAE(-3) were $-4380.622,-1243.079$ and -2847.261 respectively and as Table 3 shows they were negative and had significant effect on agricultural export at 5\% statistical level. This indicated that all the previous years' value of agricultural tax had crowding effect on the current agricultural export profile on the country as increased taxation of agricultural export commodities in the previous years. This finding is consistent with the observations of Nwibo (2012), Folawewo and Olakojo (2010) and Nwachukwu et. al. (2008) that reported that the accrued earnings from agricultural export in Nigeria have brought numerous benefits to Nigeria and the government revenue depended heavily on agricultural export taxes before the oil boom which had drastically reduced afterwards resulting from falling export earnings.

The coefficients of the NFE(-3) was -0.7726 , it was negative and statistically significant which shows that the three-year lag of net food export value had a negative short run significant effects on the current level agricultural export, This indicates that a net food export deficit generally experienced over the years had negative significant effect on the current agricultural export trend of the country. The long stay of net food export deficit borne out of the downward trend of agricultural productivity had resulted in higher food import bill experienced in the country. This implies that domestic food supply shortage in the height of ever-increasing population of the country came with the attendant rising food import bill as impacted negatively on food crop exportation. This finding is consistent with those of Olarinde and Abdullahi (2012) and Abolagba et al (2010). 
Table 3. Result of the Vector Error Correlation Model (VECM)

\begin{tabular}{|c|c|c|c|c|}
\hline Variables & Coefficient & Standard Error & $\mathbf{z}$ & $\mathbf{P}>|\mathbf{z}|$ \\
\hline $\operatorname{ECM}(-1)$ & -0.2079 & 0.0436 & -4.77 & $0.00 * * *$ \\
\hline $\operatorname{AEX}(-1)$ & -0.3863 & 0.1617 & -2.39 & $0.02 * *$ \\
\hline $\operatorname{AEX}(-2)$ & -0.7307 & 0.3049 & -2.40 & $0.02 * *$ \\
\hline $\operatorname{AEX}(-3)$ & -0.2521 & 0.3047 & 0.83 & 0.48 \\
\hline GE(-1) & -0.2167 & 0.044 & -4.88 & -0.30 \\
\hline GE(-2) & -0.1692 & 0.3127 & -5.41 & -0.23 \\
\hline GE(-3) & 0.2806 & 0.9814 & 2.86 & 0.09 \\
\hline GEA(-1) & 1.8256 & 0.4725 & 3.86 & $0.00^{* * *}$ \\
\hline GEA(-2) & 1.4223 & 0.3640 & 3.91 & $0.00 * * *$ \\
\hline GEA(-3) & 0.2341 & 0.5995 & 0.39 & 0.70 \\
\hline TAE(-1) & -4380.622 & 1579.104 & -2.77 & $0.01 * * *$ \\
\hline TAE(-2) & -1243.079 & 696.999 & -1.78 & $0.04^{* *}$ \\
\hline TAE(-3) & -2847.261 & 1504.392 & -1.89 & $0.03 * *$ \\
\hline NFE(-1) & -0.8844 & 0.6487 & -0.36 & 0.17 \\
\hline NFE(-2) & -0.6486 & 0.5004 & -1.30 & 0.20 \\
\hline NFE(-3) & -0.7726 & 0.4269 & -1.81 & $0.07 * *$ \\
\hline EXCH(-1) & 2.2767 & 0.4299 & 5.30 & $0.00 * * *$ \\
\hline EXCH (-2) & 1.2721 & 0.3477 & 3.66 & $0.00^{* * *}$ \\
\hline EXCH (-3) & 0.4535 & 0.2228 & 2.03 & $0.02 * *$ \\
\hline FDI(-1) & -1531.303 & 238.234 & -6.43 & $0.00 * * *$ \\
\hline FDI(-2) & -260.475 & 576.357 & 0.45 & 0.65 \\
\hline FDI(-3) & 32.769 & 597.357 & 0.45 & 0.65 \\
\hline CONSTANT & -880.499 & 1232.119 & -0.71 & 0.48 \\
\hline
\end{tabular}

$* * *, * *$ = significant at $1 \%, 5 \%$

Source: Results of the Data Analysis, 2016

$(-1),(-2)$ and (-3) represent 1-year lagged, 2-year lagged and 3-year lagged variables.

AIC $=-22.815, \mathrm{HQIC}=-19.993, \mathrm{SBIC}=-13.585$, Log likelihood ratio $=513.407 * * *$

The coefficients of EXCH(-1), EXCH(-2) and $\operatorname{EXCH}(-3)$ were $2.2767,1.2721$ and 0.4535 respectively, it means that exchange rate had positive short run significant effects on the current agricultural export pattern. This implies that the lower value of Nigeria's naira to US's dollar, popularly called naira devaluation to dollar, tend to increase value of agricultural export of Nigeria. This result is consistent with that of Garba (1998) who found out that exchange rate volatility was significant at $10 \%$ level and that it had the expected positive sign suggesting that the nominal devaluation of the Naira/US\$ exchange rate had a positive impact on agricultural export commodities in Nigeria but it negates the findings of Adubi and Okunmadewa (1999) and Ettah et. al. (2011), which show that exchange rate volatility impacts on cocoa export negatively which discourages cocoa export in Nigeria.

Finally, the coefficient of FDI (-1) was -1531.303 and significant at $5 \%$ statistical level, It shows that penultimate value of the foreign direct investment had negative short-run significant effect on the current status of the agricultural export. This implies that increasing foreign direct capital inflows into the Nigeria economy in form of machineries, human capital, international donor finance and other technical support in agricultural sectors had not significantly turned around the export profile of the sector. This suggests that the domestic economy had not taken full advantage of foreign investment to develop critical sectors such as agriculture and other sectors of the economy partly due to undemocratic rule, civil wars, youthful restiveness, political instability, corruption, poor macroeconomic management as witnessed since independence. This is consistent with the findings of Onu (2012).

\section{Conclusions and Recommendations}

There is long run relationship between agricultural export and fiscal policy variables and other macro-economic variables included in the model as indicated by the statistically significant ECM (-1). There is declining trend of agricultural exports over the years as reflected by the downward patterns that agricultural export had been experiencing since the oil boom in the 1970s when government attention had been diverted to 
downstream sector of the economy leaving the agricultural sector to suffer colossal loss over the years. Government expenditure, which is often below the FAO's 25\% recommendation, did not have instantaneous positive effect on the agricultural export as government expenditure on agriculture have negative effect on agricultural export as a result of late disbursement, high level of official corruption and bad governance which played out in diversion of funds to unintended beneficiaries. The value of agricultural tax had crowding effect on the current agricultural export profile on the country as increased taxation of agricultural export commodities in the previous years could be associated with decrease in the value of agricultural export in the current year. The net food export deficit generally experienced over the years had negative significant effect on the current agricultural export trend of the country due to domestic food supply shortage in the height of ever-increasing population of the country resulting in rising food import bill. The increasing exchange rate, popularly called naira devaluation to dollar, increased the value of agricultural export of Nigeria.

The increasing foreign direct capital inflows into the Nigeria economy in form of machineries, human capital, international donor funds and other technical support in agricultural sectors had not significantly turned around the export profile of the sector. This is because the domestic economy had not taken full advantage of foreign investment to develop critical sectors such as agriculture and other sector of the economy. This is partly due to undemocratic rule, civil wars, youthful restiveness, political instability, corruption, poor macroeconomic management as witnessed since independence.

Based on the conclusion of the study, it was recommended that:

- Government should strive to attain the budgetary allocation to agricultural sector of $25 \%$ as recommended by FAO and other International Agricultural Agencies in order to curb net food export deficit and ever increasing food import bill, poverty or hunger that is wagging and waxing stronger in Nigeria.

- Appropriate macro-economic policy measures should be implemented under stable political atmosphere to attract foreign capital investment. This can be in the form technical support and donor fund in order to boost increased agricultural productivity.

- Government effort should be complemented by favourable monetary policy geared towards flexible exchange rate to encourage inflows of foreign currency through FDI thereby helping Agricultural exportation to command higher value in the International market.

- The current agricultural tax policy should be scrutinized with intention to introduce favorable tax regime for agricultural commodities thereby encourage Nigerian farmers and exporters to consider exportation as a worthwhile venture.
- Official corruption and embezzlement of government expenditure meant for agriculture and other capital investments should be prosecuted according to the law of the land.

\section{REFERENCES}

[1] Abolagba, E.O; Onyekwere N.C; Agbonkpolor, B.N and Umar, H.Y, (2010). Determinants of Agricultural Exports. Journal of Humanity and Ecological. 27(3): 181-184.

[2] Adubi, A. A.and Okunmadewa, F., (1999) Price, exchange rate volatility and Nigeria's agricultural trade flows: A dynami analysis African Economic Research Consortium, Nairobi AERC Research Paper 87

[3] ATA (Agricultural Transformation Agenda), (2011): we will grow Nigeria’s Agricultural sector. Federal of Ministry Agriculture and Rural Development Abuja, Nigeria. Draft for Discussion 9th September, 2011.

[4] Ajakaiye, O and Fakiyesi, T. (2009) Global Financial Crisis Discussion Series Paper 8: Nigeria, Overseas Development Institute 111 Westminster Bridge Road, London SE1 7JD. Pp. 8-9.

[5] Akintunde O K.; Okoruwa V. O and Adeoti A. I., (2013): The Effect of Agroclimatic Factors on Cash Crops Production in Nigeria. Journal of Central European Agriculture, 2013, 14(3): 52-74.

[6] Bernard, O.A. (2009). "Empirical Analysis of Credit Supply and Agricultural Output in Nigeria”. Unpublished M.Sc Thesis of Department of Economics, Kogi State University, Ayingba-Nigeria.

[7] CBN (Central Bank of Nigeria), (2007) Statistical Bulletin. Central Bank of Nigeria.

[8] CBN (Central Bank of Nigeria), (2000): "Yields of Cash Crops in Nigeria”. Statistical Bulletin, 11(2): 56.

[9] CBN (Central Bank of Nigeria), (2005) Annual Reports and Accounts, various years.

[10] Chigbu, U.E (2000). Agriculture as the only saviour to Nigeria dyeing Economy from http://www.nigerianvillages quare. com/articles./guest/2005/03/agric-asonly saviour-to.html. assessed on 25th May, 2014.

[11] Diao, X.; Hazell, P.; Resnick, D and Thurlow, J., (2007). The role of agriculture in development: implications for sub-Saharan Africa. Research Report 153, International Food Policy Research Institute, Washington, D.C., USA.

[12] Ekerete, P. (2001). "Assessment of Agricultural Contributions to Total Export Marketing in Nigeria”. International Journal of Economic and Development Issues. 1(2): 23-45.

[13] Ekpo, A, and Egwaikhide, F., (1994): Exports and Economic Growth in Nigeria: A reconsideration of the evidence. Journal of Economics Management. 1(1):100 - 115.

[14] Emeka O.M, (2007). Improving the Agricultural Sector Toward Economic Development and Poverty Reduction in 
Nigeria. CBN Bullion, 4: 23-56.

[15] Ettah, E.B; Akpan, O.D and Etim, R.S, (2011): Effects of price and exchange rate fluctuations on Agricultural Exports in Nigeria International Journal of Economic Development Research and Investment, 2(1): 1 - 10.

[16] FAOSTAT, (2008). Food and Agriculture Organisation Statistical Database. http://faostat.fao.org assessed on $13^{\text {th }}$ October, 2014.

[17] Folawewo A O and Olakojo A O., (2010). Determinants of Agricultural Exports in oil Exporting Economy. Empirical Evidence of Nigeria. Journal of Economics theory 4 (4): 84-92.

[18] Garba, P. K. (1998). The Nigerian Economic Resources of Agriculture to Adjustment Policies. African Economic Research Consortium, Research Paper 19.

[19] Gujarati, D.N., (1995). Basic Econometrics, New York, Mc Graw Hill, 3rd Edition.

[20] Iganiga B.O. and Unemhilin D.O., (2011): The Impact of Federal Government Agricultural Expenditure on Agricultural Output in Nigeria. Journal of Economics (C) Kamla-Raj 2011, 2(2): 81-88.

[21] Itodo, A.I; Apeh, S and Adeshina, S, (2012) Governverment Expenditure on Agriculture and Agricultural Output in Nigeria (1975-2010). Journal of Agriculture and Veterinary Sciences Cenresin Publications www.cenresinpub.org, 4: 7 22.

[22] Kargbo, M. (2006). Exchange rate volatility and Agricultural trade under policy reforms in South Africa. A Research paper to African Economic Research Consortium

[23] Maddala, G. S, (1992): Introduction to Econometrics. Macmillan Publishing Company. New York. $2^{\text {nd }}$ edition.

[24] NPC (National Population Commission), (2006): Census provisional results. National Population Commission, Nigeria.

[25] Njoku, J.E and Odii, M.A.C.A., (1991). Determinants of
Loan Repayment under the Special Emergency Loan Scheme (SEALS) in Nigeria: A Case Study of Imo State. African Review of Money, Finance and Banking, Milano, Italy. 1: 39-52.

[26] Nwachukwu, I. N., Ehumadu, F. C; Majeha, R. O; Nwaru, J. C; Agwo, N. M and Onwumere, J. I. (2008) Empirical Assessment of Nigeria's Agricultural Export and Economic welfare. MPRA P.N 12631. Pp.2-38

[27] Nwibo, S. U, (2012): Effect of Agricultural Exports on Food Security in Ebonyi State, Nigeria Journal of Agricultural Research and Development 2(3). 77-82.

[28] Nwibo, S. U.; Igberi C.O.; Awoke M. U. and Odo N. E., (2012) Performance of agricultural trade liberalization on tax revenue in Nigeria: 1975 - 2009 Journal of Agriculture and Veterinary Sciences, 4:63-73

[29] Nwosu A.C (2004). Private Sector Initiative in Agricultural Development in Nigeria. CBN. Proceedings of the $13^{\text {th }}$ Annual Conference of the Regional Research Unit. University of Ibadan, August 6 to 8, 2004.

[30] Olagunju, M.A. (2000) “Economic Issues in Nigeria’s Development” in Akinbi, J.O. (ed) Towards a Better Nigeria. Ibadan: Ben Quality Press.

[31] Olarinde, M. O and Abdullahi, H., (2014) Macroeconomic Policy and Agricultural Output in Nigeria: Implications for Food Security. American Journal of Economics, 4(2): $99-113$

[32] Omanukwe, P. (2007). Agricultural Knowledge Systems, Information and Communication technologies and their implications for agricultural development in Nigeria, Bullion Publication of Central Bank of Nigeria, 31: 3138.

[33] Onu, A.J.C, (2012) Impact of Foreign Direct Investment on Economic Growth in Nigeria Interdisciplinary Journal of Contemporary Research in Business ijcrb.webs.com 4(5):64-79.

[34] Okuneye R. A. (2002). "Rising Cost of Food Prices and Food Insecurity in Nigeria and Its Implication for Poverty Reduction” CBN Economic And Financial Review 39 (4):6 